\title{
Sustainable City Priorities in Global North Versus Global South
}

\author{
Saeid Yazdani ${ }^{1} \&$ Kamariah Dola ${ }^{2}$ \\ ${ }^{1}$ Faculty of Design and Architecture, Universiti Putra Malaysia, Malaysia \\ ${ }^{2}$ Department of Landscape Architecture, Faculty of Design and Architecture, Universiti Putra Malaysia, \\ Malaysia \\ Correspondence: Saeid Yazdani, Faculty of Design and Architecture, Universiti Putra Malaysia, Malaysia. Tel: \\ 60-111-226-9581. E-mail: saeedyazdani110@yahoo.com
}

Received: April 4, 2013 Accepted: May 29, 2013 Online Published: June 13, 2013

doi:10.5539/jsd.v6n7p38 URL: http://dx.doi.org/10.5539/jsd.v6n7p38

\begin{abstract}
The paper sought to compare between the meaning of city sustainability concept in the Global North and Global South. The majority of existing sustainability concepts and goals, defined in developed countries, do not cover the main problems of cities in developing countries. While most of the sustainability discourses in industrialized countries refer to environmental issues, developing countries are still involved with economic and social matters such as poverty, social injustice, gender discrimination. Despite the fact that, the main part of climate change causes are produced in developed countries, people in developing countries are struggling with the negative effects of climate change. To put it more precisely, developing nations' citizens, who are not responsible for climate change, are climate change vulnerable populations. Based on a review of literature, this article concludes that, in the current global imbalance situation, a universal strategy "one size fit for all" of sustainability city cannot be applied to cities all around the world. Moreover, "inter-nations responsibility" is a missing key point in sustainability-related literature. To this end, it is necessary to revise the sustainability-related concepts in order to apply in the Global South.
\end{abstract}

Keywords: sustainable city, sustainability concept, Global North, Global South

\section{Introduction}

The notion of sustainability has been a key concept in regional, national and international discussion following the dissemination of two documents: the club of Rome's Limits to Growth (Meadows, 1972) and, the more famous one, the Brundtland commission's Our Common Future (UN World Commission on Environment and Development, 1987). In this regard, the 1992 Rio Earth Summit (Hibbard et al., 2007) has played a noteworthy role in the generalization of the sustainability agenda and debate. Many authors and researchers have accepted that the concept of sustainable development is not one that can readily be grasped by the wider public (Hammond, 1998; Zaccai, 2012). According to Parkin, in 2000 there are more than two hundred definitions of sustainable development and the number keeps on rising. This is due to the fact that sustainable development is time dependence and spatial dependence. As it concerns intergenerational goals, it requires long-term perspective, and it should be locally specific rather than using standardized, universal objectives (Berardi, 2013). Happearts (2012) asserts that the world has changed rapidly since the first conception of sustainable development but most of the problems that gave rise to the introduction of the concept has not been solved, and worse, we continue to witness irreversible loss of natural resources, rapid depletion of certain energy resourses, troubling climate change and social injustices.

It is a fact that cities are the core of any sustainable development. The growing urgency to enhance sustainability of existing and emerging cities was stressed by Pickett et al. (2013), as not all possible urban transformations may lead towards sustainability. The building and rebuilding of cities in a sustainable manner are grand challenges, remarkably in the cities of Global South where their debt burden and inequalities in global income allocation are seen as vital obstacles to sustainable development (Thring, 1990).

It is projected that the majority of future population growth will take place in urban areas, with urban populations expected to reach $5.26 \times 10^{9}$ by 2050 (Montgomery, 2008), this figure is almost equivalent to 65 per cent of the total estimated global population for the year of 2050 (Pacione, 2007). Africa, Asia and Latin America will be the home of approximately 90 per cent of the added urban population (UN, 2004). Pickett et al. (2013) warn that 
smaller cities in the Global South may not have the resources to provide healthy, well-functioning systems to support the unprecedented growth. This extraordinary urbanization and urban population growth, mostly in undeveloped nations, have motivated scholars and policy makers to explore for sustainable urban development alternatives which can manage major societal and environmental upheavals (Pickett et al., 2013; Childers et al., 2013). Evidently, with regard to the vibrant nature of cities, relying on common aims and policies to strike a worldwide sustainable city concept is not without controversy. It can be claimed that, for instance, current sustainable city dialogues are derived by goals that are pertinent to the Global North's cities. Myllyla and Kuvaja (2005) state that the goals and approaches which have been derived by the developed nations carry inherently their characteristics that may have particular limitations for applying in developing countries.

Hence, with respect to the fact that socioeconomic features and cultural resources are widely diverse, the equal goals of sustainability cannot be appropriated for all cities world wide. In the line with this paradigm this paper claims that concepts, indicators and goals of sustainable city which have been organized for Global North cannot, or should not be applied to Global South without any localization. In the other words, consideration of Global South priorities, such as poverty, starvation, unemployment, etc., is a key success for organizing sustainable goals and criteria for third world countries.

This paper is based on reviewing existing literature, which have been gathered from publications such as books, print journals, online journals, reports and online information. Following explaining the genesis of "sustainable development", sustainable city and urban sustainability indicators, this paper poses some critical questions; whether the current approaches meant to deal with urban sustainability issues, effectively address the main sustainability concerns of cities in developing countries.

\section{Sustainable Development and Sustainable City}

The term sustainable development has been used for many purposes by various individuals such as scholars, politicians, NGOs, conservationists and ecologists. Following its two prevalent documents, "The Club of Rome's Limits to Growth" and "Our Common Future", sustainability seems to have an expanding literary life of its own (Savage, 2006). From the time when "the Club of Rome's Limits to Growth" has been disseminated, in 1972, there have been numerous explanations of sustainability invented. As this term is open to different interpretations, Zaccai (2012) sarcastically wrote that the multiplicity of interpretations, its openness and plasticity to every context has always been a kind of game that academic, political and social actors can play. Nevertheless, the most popular quoted definition of sustainable development is "development that meets the needs of the present without compromising the ability of future generations to meet their own needs" (WCED, 1987).

Allen (1980) point outs that a development can be labelled as sustainable development if it can satisfy the need of current generation and improve the quality of life under the circumstance that allows the utilized ecosystem and natural resources to keep renewing themselves. This definition, connects the "quality of life" to "ecosystem conservation", which implies the discussion of weak sustainability. Recalling that the notion of weak sustainability implies the state that human capital systems are in a straight line substitutable for natural capital systems. However, United Kingdom's Round Table on Sustainable Development (1999) contend that the quality of life is only part of what is meant by sustainable development and it would be inopportune if the two phrases became synonymous in the 'public mind'. Hammond (2000) defines sustainability as striking a balance between economic and social development with environmental protection,"people, planet, prosperity", or the so-called "triple bottom line" (Parkin, 2000).

Baumgärtner and Quaas (2010) state that sustainability is a normalized conception that shows the appropriate and necessary interaction between human beings and nature, and how community is responsible towards next generations. The foundation for sustainable development is to satisfy basic human needs under a circumstance that preserves the life-support systems of our planet (Kates, Clark, \& Corell, 2001). These two definitions involve a robust element of inter-generational ethics: what John Gummer, former UK Secretary of State for the Environment (1993-1997), summarized in the phrase "don't cheat on your children" (Parkin, 2000). However, both these explanations carry the vagueness of the definition of sustainable development in the Report of the Brundtland Commission, discussing "inter-generational responsibility" and "human needs".

The concept of "the triple bottom line" can more abstractly address the interrelationship between the economic growth rate, quality of life and conservation of ecosystems and capital nature. Elkington (1997) believes that sustainable development should cover "the triple bottom line" which takes into account social justice, economic development and quality of the environment. The phrase of triple bottom line represents a nested hierarchy 
(Fischer \& Manning, 2007). In other words, with no clear function of life support system and lack of social strong structure, economics and community cannot flourish.

Despite of numerous definitions of sustainability, several common points can be elicited among them as listed by Gasparatos et al. (2008): inter-generational equity consideration; respect to consequences of current actions into the future; considering ecological, social and economic issues; engage the public; and affirm the existence of doubts concerning the result of our present actions with a precautionary bias. However, in spite of the common features in the descriptions of sustainability, there is no universal consensus on sustainability definition and indicators. Hall (1998) argues that the controversial point of this definition is that "needs" has not been clearly defined and, furthermore, the definition of sustainability is unrealistic and to some extent not practical. Blowers and Pain (1999) as well point out that "what may be regarded as needs in the cities of the North would be luxuries in those of the South". Therefore, determining the same sustainability goals for cities in North and South and, as well, applying the same criteria for assessing sustainability in both North and South global would certainly be debatable. In the following sections, the genesis of the notion of sustainable cities and sustainability indicators would be discussed, respectively.

\subsection{Sustainable City}

Jenks and Dempsey (2005) defined sustainable city as cities that ensure the well-being and a good quality of life for citizens, environmentally friendly and socially integrated and just. Urban development areas play a pivotal role in all around the world, since human being community and fiscal activities are centralized there, cities are the focal points of many human activities (Breheny, 1992). There are three significant tendencies in the urbanization process (UN-Habitat, 2006): firstly, the largest cities would be found mostly in the Global South countries: 'Metacities', defined by UN as a metropolitan area with a total population of more than 10 million people, are now growing in Latin America, Africa and Asia. Secondly, more than half of the globe's urban inhabitants live in cities with less than 500,000 people. Thirdly, by 2030, Global South cities will be house of $95 \%$ of urban growth in the next two decades. Notwithstanding the important role of cities in socioeconomic aspect, they perform inadequately in the context of ecological protection due to their externalities. However, it is obvious that plenty of the discussion about sustainability has a city focus. As Breheny (1992, p. 2) points out, "The world's cities are the major consumers of natural resources and the major producers of pollution and waste. Thus, if cities can be designed and managed in such a way that resource use and pollution are reduced, then a major contribution to the solution of the global problem can be achieved". However, despite of the popularity of sustainability in many academic disciplines, the definition of sustainability has its inherent vaguenesses. Moreover, the notion of sustainability at the city level has particular features (Bithas \& Christofakis, 2006).

An urban area can be one of significant Economic Spatial Analysis units for assessing sustainability but it is usually difficult to identify the spatial unit or determine the boundaries of cities. An urban area can be identified in terms of its population; function; land use; ratio of built and not built area and so forth. According to the United Nation's definition, an urban area can be defined as the built-up area or densely populated area including the suburbs and incessantly settled commuter area, which be smaller than a metropolitan area (UN-Habitat, 2006). However, there are a dozen of notions related to urban sustainability, which are comparable in several common points.

Register (1987) in his well-known book, "Ecocity Berkeley", for the first time coined the term "ecocity": building cities for a healthy future. An eco-city or sustainable city is a city with respect to environmental impact. A sustainable city is supposed to meet the needs of the current generation without compromising the ability of future generations to meet their own needs. Buckingham and Turner (2008) believe that urban sustainability depends on interrelationship between environment and community, which is fundamentally a creation of dominant and influential groups in that society. There is no widely accepted definition of sustainable city. However, there are numerous definitions, let's look at a few of them:

Haughton and Hunter (1994, p. 27) describe a sustainable city as:

"One in which its people and businesses continuously endeavour to improve their natural, built and cultural environments at neighbourhood and regional levels, whilst working in two ways which always support the goal of global sustainable development"

Camagni, Capello and Nijkamp state that urban sustainable development is:

"A development which ensures that the local population can attain and maintain an acceptable and non-declining level of welfare, without jeopardizing the opportunities of people in adjacent areas" (1998, p. 106).

Girardet (1999) describes the sustainable city as: 
"An organized so as to enable all its citizens to meet their own needs and to enhance their well-being without damaging the natural world or endangering the living conditions of other people, now or in the future."

The definition of sustainable city, however, remains vague and to some extent unacceptable. Furthermore, this question can be raised whether the vision of a sustainable city can be considered as a base for sustainable development.

Regardless of the ambiguity in the definition of a sustainable city, sustainability aspects have been indicated in broad ways in the different parts of the globe, in relation to the priorities in the process of decision making and environmental challenges in cities and countries (UN-Habitat, 2006). There are meaningful distinctions between stages of development in the Global North and South. In Global North, environmental aspects are in the focal point of sustainability discussions, while in Global South poverty and social justice issues are equally important (Kemmler \& Spreng, 2007). In line with these issues, urban sustainability issues can be categorized into two distinct agendas (McGranahan \& Satterthwaite, 2000), green agenda and brown agenda. Green agenda refers to environmental problems which have long-term impacts, namely, ecosystem disruption by mass consumption and waste accumulation, resource degradation and global change (McGranahan \& Satterthwaite, 2000). On the other hand, brown agenda refers to unsanitary living condition, dangerous pollutants in urban air and waterways and unsanitary disposal of waste, especially in Global South's cities where a majority of urban dwellers is poor (Savage, 2006).

Hence, sustainability-related issues would be challenging and problematic, especially in developing countries. Whereas the major priorities of societies in developing countries are associated with brown agenda, setting goals based on the green agenda could not be acceptable. While, in the other words, a large portion of urban dwellers in the Global South are struggling with poverty and social inequality, delineating sustainable vision only based on eco-related issues cannot certainly be rationalistic and realistic.

\subsection{Sustainability Indicators}

The purpose of City Sustainable Index (CSI) is to evaluate and compare cites' sustainable performance in order to understand the influence of cities on the natural world and human being's life. Pope et al. (2004) point out that in sustainability assessment, the triple bottom line of sustainability (abbreviated as 3BL or TBL, and also known as people, planet, profit or "the three pillars") is a starting point. Parris and Kates (2003) argue that the purposes of sustainability assessment can be classified in four foremost intents: participation and consensus building; decision making and management; advocacy, participation and consensus building; and research and analysis.

In order to assess the sustainability performance a large number of sustainability indicators have been invented. The most famous of them can be enumerated as follows: Ecological Footprint (EF); PEIA (Planning Environmental Impact Assessment); Environmental Sustainability Index (ESI); SEA (Strategic Environmental Assessment); Dashboard of Sustainability (DS); Welfare Index (WI); Genuine Progress Indicator (GPI); City Development Index (CDI); Index of Sustainable Economic Welfare (ISEW); Emergy/Exergy; Living Planet Index (LPI); Human Development Index (HDI); Environmental Policy Index (EPI); Environmental Vulnerability Index (EVI); Genuine Saving (GS); Environmentally-adjusted Domestic Product (EDP); and so forth.

Critical reviewing of the aforementioned indicators would reveal that they are mostly concerned about environmental problems in the Global North and they cannot address the main problems of cities in the Global South. "Carbon Leakages" between the industrialized countries and developing countries, for instance, are generating severe obstacles for the developing countries, but existing indicators do not take it into account. "Carbon leakage" happens when there is an increase in carbon dioxide emissions in one country as a result of an emissions reduction by a second country with a strict climate policy. This may take place once industrialized countries offshore their production facility outside their country to reduce their carbon footprint. Additionally, leakage of carbon dioxide stored underground is also termed as 'carbon leakage'. Mayer (2008) point out that Leakages take place when global North with strict environmental control standards import raw materials and export waste and pollution-intensive products, to keep their environment jurisdiction in the highest quality condition.

Therefore, it can be posed that as "inter-generation responsibilities" is one of the key points in sustainability-related concepts, "inter-nations responsibilities" should be considered in any sustainability definition. In the other words, "inter-nations responsibilities" is equally important as "ecosystem responsibilities" and "inter-generation responsibilities". 


\section{Bias on Sustainability Connotations: A Few Critical Inquiries}

The preceding sections of the paper dedicated to the notion of 'sustainable development', 'sustainable city' and the purpose of sustainability indicators. Aforementioned discourses revealed that these concepts and approaches do not adequately address the major problem of the cities in the Global South. Purvis and Grainger (2005) criticize the idea of development, shaped by developed nations, although was well-meaning intended to reduce the gap that separated them from the 'poor' countries had failed to realized the developmental ideal. Instead, majorities of developing countries suffered from poverty, famine and ill-health. Consequently, universal inventiveness in developing countries accentuates the minor aspects more than major aspects. In the line with these, as Aguilar and de Fuentes (2007) argue in the present day, the city [in Global South] is characterized by a number of complicated urban facts, with serious social and environmental problems, including ghettos areas, a large portion of the inhabitants with insufficient access to basic urban infrastructure (particularly potable water and sewerage), and polluted groundwater. In the other words, cities, especially in developing countries, are characterized by a range of urban dilemmas, including a high cost of living; rural-urban migration; segregation and fragmentation of urban districts; urban land invasions; a huge number of the workforce relying on the informal economy; lack of environmental awareness among construction companies and developers; the privatization of civil infrastructure (in particular piped water and sewerage networks) and poor public management. In spite of few outcomes in city sustainability agendas, greater than ever unsustainability in the developing countries raises some questions, which are enumerated as follows.

\subsection{Who is Responsible? Who is Vulnerable?}

It is obvious that man-caused climate change is undeniable fact and it is a tremendous threat to the globe and its dwellers. Recent facts reveal that in order to have a possibility of staying under an average temperature rise of over $2^{\circ} \mathrm{C}$, we need to reduce greenhouse-gas emissions in developed countries by at least $80 \%$ by 2050 (Woods, Williams, Hughes, Black, \& Murphy, 2010). Nevertheless, while industrialized countries are in charge for 60 per cent of the greenhouse gas emissions that contribute to climate change, developing countries undergo the "worst and first" effects of climate-related disasters, including droughts and storms, because of their geographical locations (Timmons Roberts \& Parks, 2006). The universal discussion about who must take action to address climate change is tremendously uncertain, as completely opposed perceptions of climate justice threaten the prospects for any long-term agreement. The 'Kyoto Protocol', the United Nations Framework Convention on Climate Change (UNFCCC) adopted on 11 December 1997 in Kyoto, Japan, and entered into force on 16 February 2005, For instance, cannot be assessed as a successful international treaty. Because, the United State of America did not ratify the Protocol and Canada withdrew from it in 2011 (GILLIES, 2011). Timmons Roberts and Parks (2006) point out that universal inequality dampens down cooperative efforts by reinforcing the "structuralist" worldviews and causal beliefs of many poor nations, eroding conditions of generalized trust, and promoting particularistic notions of "fair" solutions.

As an example of climate effects on the Global South, The drought that devastated East Africa in 2011 was reported by the $\mathrm{BBC}$ to be the worst in 60 years (BBC, 2011). As the rains failed and the ground became burnt, tens of thousands of families start out in search of food and water for themselves and their livestock, struggling to find places that were better than where they had come from. The BBC reported that an estimated 100,000 people died from the famine caused by the drought. Severe weather events such as these are forecast to become more common as the effects of climate change worsen (Pachauri \& Reisinger, 2007).

Notwithstanding this fact that industrialized countries are the main producer man-made causes of global climate change such as greenhouse gas (GHG) emission, developing countries are affected by climate change, because of their geographical location (Timmons Roberts \& Parks, 2006). "Developed countries had become so wealthy by despoiling their environment .... So it was seen as hypocritical of the former now to ask developing countries to protect their environment and control population growth at the expense of the chance of economic development" (Purvis \& Granger, 2005, p. 4). Low-income people and poor institutions, and their greater dependence on climate-sensitive sectors like agriculture, are more likely to suffer from climate change effects. Developing countries are the most vulnerable to risks associated with droughts, floods, coastal storms and changes in agricultural productivity. Existing sustainability concepts and indicators cannot adequately address this unfavorable relationship. The issue at stake is not the climate change impacts alone, but involves interdependent of global players, in which one disaster may affect the other, although not directly. For example, the flooding in Thailand in September 2011 had greatly affected the local production but also global supply (http://www.unescap.org/tid/artnet/pub/polbrief34.pdf). Therefore, the shortcomings of urban sustainability discourses is that they are not able to explain satisfactorily injustice relationship between developed countries and developing countries, but also intricate interdependency between them. 


\subsection{Conflicting Agendas? Helping the Poor Versus Protecting the Future}

Discourse between advocates of the green and brown agendas began to emerge through the major results of the United Nation summits in Rio de Janeiro (the environment-focused Agenda 21) and Istanbul (the urban-focused Habitat Agenda). Perfunctorily at least, these two agendas are in conflict with each other. From a 'green' point of view, relocating environmental burdens is unjust and economically unsafe. It transfers the burdens from those who produced them onto remote people and ecosystems, and even onto coming generations. From a 'brown' point of view, the basic injustices and economic inefficacies lie in the insufficient local water supplies, lack of waste collection, local air pollution, deficient sanitation and inadequate land available to the poor. In terms of justness, poor people have the right to have their basic needs met - if necessary by the same means which others have, historically, met theirs. Moreover, the Habitat Agenda especially recognized that, in a more and more urbanized world, cities are the spot of critical social, economic and environmental problems, as well as comprising unique opportunities for a more sustainable future (Allen \&You, 2002).

However, most of the cities in the Global South are facing with problems of brown agenda (Myllyla \& Kuvaja, 2005). According to United Nations Population Fund (2007), in 2001 about 31 per cent of the global urban population, 924 million people, were living in spontaneous settlements or ghettos; 90 per cent of which were located in the developing countries. Of the 60 million people added to the world's urban population every year, most move to informal settlements with no sanitation facilities (UN Water, 2008). Up to 2030, the number of slum residents is projected to reach two billion (UN-HABITAT, 2007). In Dhaka in Bangladesh, for instance, 3.4 million of the urban's 13 million dwellers live in 5,000 slums and squatter settlements (IRIN, 2008). According to Prüss-Üstün, Bos, Gore and Bartram (2008) over 3.4 million people die each year from water, sanitation, and hygiene-related causes. Nearly all deaths, 99 percent, occur in the developing world. Furthermore, in dense slum environments Contagious Diseases can quickly become epidemics, making the result of non-potable water and poor sanitation much more severe than in rural areas.

The situation of brown issues in the Global South illustrates that the current definitions and indicators pertained to sustainable cities do not address the environmental health issues in the Global South. Shiva (1993) argues that the priorities of global sustainability related agendas have created a condition in which global problems such as climate change which have mainly been caused by the Global North, are expected to be solved by South through Northern innovations. Hence, it can be claimed that global sustainability discourses do not give priority to 'brown agenda' of the Global South as much as 'green agenda'.

\subsection{Do Urban Sustainability Discourses Take into Account the Urban Population Growth?}

At the present time, more than $50 \%$ of the globe's population live in cities. By 2050 , this estimation is projected to be $70 \%$ (Zipperer \& Pickett, 2012). This unprecedented urban population growth, however, is not uniformly distributed across the earth. The majority of urban population growth will occur in developing countries and create megacities, cities whose populations exceed 10 million people. In developing nations, in the other words, the dominant form of dwellings are changing swiftly, from rural dwelling form to urban form. Kasarda and Rondinelli (1990) argue that a comparable kind of Industrial Revolution, which took place in industrial countries in late 19th century, is now happening in the developing nations. In accordance with Far Eastern Economic Review, by 2025, only Asia will have more than 10 hypercities, cities whose population exceed of 20 million, including Bombay (with a staggering 33 million); Shanghai (27 million); Karachi (26.5 million); Dhaka (25 million); Jakarta (24.9 million people); and Shanghai (27 million) (Davis, 2004). As a result, a high urban population growth rate will be expected to observe in the Global South during the next few decades. At this point, the critical question should be asked is that whether the high pace of urban population growth has been considered in global sustainable city discourses or not?

Payne (2005) argues that research has illustrated global-based development policies can only serve only a small portion of the total population. According to estimation of the United Nations (2003), currently 924 million people are living in informal dwelling areas, and this figure would be increased to 1.5 billion by 2020 and more than 2 billion by 2030. Thus far, however, several scholars (see, for instance, Cohen, 2004; McCarney et al., 1995; Atkinson, 1994) have indicated that urban population growth, especially in developing nations, has not been included in global sustainable urban developments. Therefore, with respect to high rate of urban population growth in developing nations, the targeted population of sustainable city would be only a minority of urban dwellers not all. 


\section{Conclusion}

In the contemporary global context, the notion of city sustainability is a common expectation for both Global North and the Global South. But, in the a world full of disparities, as an example, according to the World Bank (2011), the GDP per capita in the richest and poorest countries was 89,012 and 373 PPP\$ respectively, a universal approach "One cap fits all" of urban sustainability definitely would be arguable. In the line with this perspective, in this article, we review major sustainability concepts and indicators in the context of their application for the Global South. This paper provides a paradigm to probe in the context of the real sustainable city priorities in developing nations.

The coming out of the Millennium Development Goals (MDGs) points to the intercontinental recognition that these kind of inequalities are not acceptable, these disparities reflect a denial of socioeconomic and political rights. Payne (2005) claims that a target-driven policy agenda, based on Global North priorities, detracts attention from the real issues, which Global South nations are grappling with them. In the sustainability discourses, these disparities reflect the rights and demands in environmental terms of the so-called 'brown' agenda.

Hence, in setting goals for sustainable city and determining indicators in order to evaluate and compare cites' sustainable performance, both "inter-generational responsibilities" and "inter-nations responsibilities" should be given equal priorities. Moreover, in our unequal world, a common approach of sustainability city cannot be applied to cities all around the world. Therefore, it is necessary to revise the sustainability concepts and goals for applying in the Global South and Global North.

\section{References}

Aguilar, M. D., \& de Fuentes, A. G. (2007). Barriers to achieving the water- and sanitation-related Millennium Development Goals in Cancun, Mexico at the beginning of the twenty-first century. Environment and Urbanization, 19(1), 243-260. http://dx.doi.org/10.1177/0956247807076918

Allen, A., \& Nicholas Y. (Eds). (2002). Sustainable Urbanization: Bridging the 9. Green and Brown Agendas, UCL Development Planning Unit in collaboration with DFID and UN-Habitat, London.

Allen, A., \& You, N. (2002). Sustainable urbanisation. Building the green and brown agenda. London: Development Planning Unit.

Allen, R. (1980). How to save the world. New Jersey: Barnes and Noble.

Atkinson, A. (1994). The contribution of cities to sustainability. Third World Planning Review, 16(2), 101-97.

Baumgärtner, S., \& Quaas, M. (2008). What is sustainability economics? Ecol Econ, 2010, 69, 445-450. Bell S, Morse S. Sustainability indicators: measuring the immeasurable? Second edition. London: Earthscan.

BBC. (2011). Save the Children Says East Africa Appeal Best in History. Retrieved Jaurary 1, 2013, from http://www.bbc.co.uk/news/uk-16333457

Berardi, U. (2013). Clarifying the new interpretations of the concept of sustainable building. Sustainable Cities and Society, 8, 72-78. http://dx.doi.org/10.1016/j.scs.2013.01.008

Bithas, K. P., \& Christofakis, M. (2006). Environmentally sustainable cities: critical review and operational conditions. Sustain Dev, 14, 177-189. http://dx.doi.org/10.1002/sd.262

Blowers, A., \& Pain, R. (1999). The unsustainable city. In S. Pile, C. Brook, \& G. Mooney (Eds), Unruly Cities? Order/Disorder, Routledge, London.

Buckingham, S., \& Turner, M. (2008). Understanding Environmental Issues. Sage, Los Angeles, CA.

Breheny, M. (1992). Sustainable development and urban form. London: Pion.

Camagni, R., Capello, R., \& Nijkamp, P. (1998). Towards sustainable city policy: an economy environment technology nexus. Ecol Econ, 24, 103-118. http://dx.doi.org/10.1016/S0921-8009(97)00032-3

Cohen, B. (2004). Urban Growth in Developing Countries: A Review of Current Trends and a Caution Regarding Existing Forecasts. World Development, 32(1), 23-51. http://dx.doi.org/10.1016/j.worlddev.2003.04.008

Elkington, J. (1997). Cannibals with forks: the triple bottom line of the 21st century business. Oxford: Capstone.

Fischer, J., \& Manning, A. D. (2007). Steffen W, et al. Mind the sustainability gap. Trends Ecol Evol, 22(12), 621-624. http://dx.doi.org/10.1016/j.tree.2007.08.016 
Gasparatos, A., El-Haram, M., \& Horner, M. (2008). A critical review of reductionist approaches for assessing the progress towards sustainability. Environ Impact Assess Rev, 28, $286-311$. http://dx.doi.org/10.1016/j.eiar.2007.09.002

GILLIES, R. (December 12, 2011). Canada formally pulls out of Kyoto Protocol on climate change. In startribune. Retrieved February 6, 2013, from http://www.startribune.com/

Girardet, H. (1999). Creating Sustainable Cities. Green Books, Totnes.

Hall, T. (1998). Urban Geography. Routledge, London.

Hammond, G. P. (1998). Alternative energy strategies for the United Kingdom revisited: market competition and sustainability. Technological Forecasting and Social Change, 1998(59), 131-151. http://dx.doi.org/10.1016/S0040-1625(97)00151-0

Hammond, G. P. (2000). Energy, environment and sustainable development: a UK perspective. Trans IChemE Part B: Process Safetyand Environmental Protection, $304-323$. http://dx.doi.org/10.1205/095758200530826

Happaerts, S. (2012). Sustainable Development and subnational governments: Going beyond symbolic politics? Environmental Development, 4, 2-17. http://dx.doi.org/10.1016/j.envdev.2012.07.001

Haughton, G., \& Hunter, C. (1994). Sustainable Cities, Regional Policy and Development Series 7, Jessica Kingsley Publishers, London.

Hibbard, K. A., Crutzen, P. J., Lambin, E. F., Liverman, D. M., Mantua, N. J., McNeill, J. R., et al. (2007). Group report: Decadal-scale interactions of humans and the environment. In R. Costanza, L. J. Graumlich, \& W. Steffen (Eds.), Sustainability or collapse? (pp. 341-377). Cambridge, MA: MIT Press.

IRIN (UN Office for the Coordination of Humanitarian Affairs). (2008). Tomorrow's crises today: the humanitarian impact of urbanization - overview. Retrieved December 6, 2012, from www.irinnews.org/

Jabareen, Y. (2013). Planning the resilient city: Concepts and strategies for coping with climate change and environmental risk. Cities, 31, 220-229. http://dx.doi.org/10.1016/j.cities.2012.05.004

Jenks, M., \& Dempsey, N. (2005). Future Forms and Design for Sustainable Cities. Architectural Press: Amsterdam.

Kasarda, J. D., \& Rondinelli, D. A. (1990). Mega-cities, the environment, and private enterprise: toward ecologically sustainable urbanization. Environmental Impact Assessment Review, 10, 393-404. http://dx.doi.org/10.1016/0195-9255(90)90031-T

Kates, R. W., Clark, W. C., Corell, R., Hall, J. M., Jaeger C. C., Lowe, 1., ... Svedin, U. (2001). Sustainability science. Science, 292(5517), 641-642. http://dx.doi.org/10.1126/science.1059386

Kemmler, A., \& Spreng, D. (2007). Energy indicators for tracking sustainability in developing countries. Energy Policy, 35, 2466-2480. http://dx.doi.org/10.1016/j.enpol.2006.09.006

Mayer, A. L. (2008). Strengths and weaknesses of common sustainability indices for multidimensional systems. Environ Int, 34, 277-291. http://dx.doi.org/10.1016/j.envint.2007.09.004

McCarney, P., Halfani, M., \& Rodriquez, A. (1995). Towards an understanding of governance: the emergence of an idea and its implications for urban research in developing countries. In R. Stren, \& B. Kjellberg (Eds), Perspectives on the City (pp. 91-142). Centre for Urban and Community Studies, University of Toronto, Toronto.

McGranahan, G., \& Satterthwaite, D. (2000). Environmental health or ecological sustainability? Reconciling the brown and green agendas in urban development. In C. Pugh (Ed.), Sustainable Cities in Developing Countries: Theory and Practice at the Millennium. Earthscan, London.

Meadows, D. H. (1972). The Limits to Growth. Potomac Associates, New York, 1972.

Montgomery, M. R. (2008). The urban transformation of the developing world. Science, 319, 761-764. http://dx.doi.org/10.1126/science. 1153012

Myllyla, S., \& Kuvaja, K. (2005). Societal premises for sustainable development in large southern cities. Global Environmental Change, 15(3), 224-237. http://dx.doi.org/10.1016/j.gloenvcha.2005.01.001

Pachauri, R. K., \& Reisinger, A. (2007). Contribution of Working Groups I, II and III to the Fourth Assessment Report of the Intergovernmental Panel on Climate Change. In IPCC. Retrieved Janurary 2, 2013, from 
http://www.ipcc.ch/publications_and_data/ar4/syr/en/contents.html

Pacione, M. (2007). Sustainable urban development in the UK: rhetoric or reality? Geography, 92(3), 248-265.

Parkin, S. (2000). Sustainable development: the concept and the practical challenge. Proceedings of the Institution of Civil Engineers. Civil Engineering, 138, 3-8. http://dx.doi.org/10.1680/cien.2000.138.6.3

Parris, T., \& Kates, R. (2003). Characterizing and measuring sustainable development. Annu Rev Environ Resour, 28, 559-586. http://dx.doi.org/10.1146/annurev.energy.28.050302.105551

Payne, G. (2005). Getting ahead of the game: a twin-track approach to improving existing slums and reducing the need for future slums. Environment and Urbanization., 17(1), 135-45.

Pickett, S. T. A., Christopher, G., Boone, B. P., McGrath, M. L., Cadenasso, D. L., Childers, L. A., ... J. Morgan Grove. (2013). Ecological science and transformation to the sustainable city. Cities, available online 6 April 2013.

Pope, J., \& Annandale, D. (2004). Morrison-Saunders A. Conceptualising sustainability assessment. Environ Impact Assess Rev, 24, 595-616. http://dx.doi.org/10.1016/j.eiar.2004.03.001

Prüss-Üstün, A., Bos, R., Gore, F., \& Bartram, J. (2008). Safer water, better health: costs, benefits and sustainability of interventions to protect and promote health. World Health Organization, Geneva.

Purvis, M., \& Grainger, A. (Eds.) (2005). Exploring sustainable Development: Geographical Perspectives. Earthscan Publication Limited: London.

Register, R. (1987). Eco-city Berkeley: building cities for a healthy future. Berkeley: North Atlantic Books.

Savage, V. R. (2006). Ecology matters: sustainable development in Southeast Asia. Sustainability Science, 1(1), 37-63. http://dx.doi.org/10.1007/s11625-006-0002-9

Shiva, V. (2007). The Violence of the Green Revolution. Third World Agriculture, Ecology and Politics, Zed Books, London.

Thring, M. W. (1990). Engineering in a stable world. Science, Technology and Development, 8(2), 107-121.

Timmons, R. J., \& Bradley, P. (2006). A Climate of Injustice: Global Inequality, North-South Politics, and Climate Policy, (Global Environmental Accord: Strategies for Sustainability and Institutional Innovation). The mit press Cambridge, Massachusetts Lond, England.

UN-Habitat (United Nations Human Settlements Programme). (2006). The state of the world's cities report 2006/2007. London: Earthscan.

UN-Habitat. (2007). Forced Evictions: Towards Solutions, Second report of the Advisory Group on Forced Evictions to the Executive Director of UN-Habitat. AGFE and UN-Habitat, Nairobi.

United Nations. (2004). World urbanization prospects: the 2003 revision Data tables and highlights. New York: United Nations.

United Nations Population Fund (UNFPA). (2007). State of World Population 2004 - The Cairo Census at Ten: Population. Reproductive Health and the Global Effort to End Poverty, UNFPA, New York, NY.

UN Water. (2008). Tackling a global crisis: International Year of Sanitation 2008. Retrieved from www.unwater.org/

UN World Commission on Environment and Development. (1987). Our Common Future. Oxford University Press, London.

UK Round Table on Sustainable Development. (1999). Fourth annual report. London: DETR.

WCED. (1987). Our common future. Oxford University Press.

Woods, J., Williams, A., Hughes, J. K., Black, M., \& Murphy, R. (2010). Energy and the food system. Philosophical transactions of the Royal Society of London. Series B, Biological sciences, 365(1554), 2991-3006. http://dx.doi.org/10.1098/rstb.2010.0172

World Bank. (2011). World Development Indicators database. Retrieved February 3, 2013, from http://databank.worldbank.org

World Resources Institute in collaboration with the United Nations Environment Programme. (1996). The United Nations Development Programme, and the World Bank, World Resources Report 1996- 97 (Oxford University Press, New York. 
Zaccai, E. (2012). Over two decades in pursuit of sustainable ddevelopment: Influence, transformations, limits. Environmenta Development, 1(1), 79-90. http://dx.doi.org/10.1016/j.envdev.2011.11.002

Zipperer, W. C., \& Pickett, S. T. (2012). Urban Ecology: Patterns of Population Growth and Ecological Effects. eLS.

\section{Copyrights}

Copyright for this article is retained by the author(s), with first publication rights granted to the journal.

This is an open-access article distributed under the terms and conditions of the Creative Commons Attribution license (http://creativecommons.org/licenses/by/3.0/). 